\title{
THE DIVERSITY OF FUNGI COLONIZING NECROTIC INFLORESCENCE BUDS OF RHODODENDRON (Rhododendron L.)
}

\section{Małgorzata Żołna, Barbara Kierpiec-Baran, Maria Kowalik}

\author{
Department of Plant Protection, Faculty of Horticulture, University of Agriculture in Krakow \\ Al. 29-Listopada 54, 31-425 Kraków, Poland \\ e-mail: gosia_zolna@interia.pl
}

Received: 10.11.2012

\begin{abstract}
The infection of rhododendron (Rhododendron L.) inflorescence buds caused by pathogenic fungi induces its browning, withering, and dieback.

The identification of fungi causing the infection of rhododendron inflorescence buds can be a reason for creating new improved cultivars with genetically determined resistance to pathogens.

The investigations were carried out in 2010-2011 on the collection of ornamental plants of the Faculty of Horticulture, University of Agriculture in Kraków. The material comprised infected inflorescence buds collected from nine newly bred taxa and one botanical species of rhododendron.

596 colonies of fungi belonging to 31 species were isolated from infected rhododendron inflorescence buds. The dominant species were: Pestalotiopsis sydowiana, Truncatella truncata, Alternaria alternata, Phialophora asteris, and Trichoderma viride, which constituted almost $74 \%$ of the isolated fungi population. Boeremia exigua var. exigua, Epicoccum nigrum, Fusarium poae, Mammaria echinobotryoides, Paraphoma chrysanthemicola, Phialophora cyclaminis, Phoma eupyrena, Talaromyces wortmannii, Umbelopsis isabellina, and other fungi were isolated in a lower number.

The results of mycological analysis confirm the diversity of species colonizing necrotic inflorescence buds of rhododendron.
\end{abstract}

Key words: Rhododendron, inflorescence buds, dieback, pathogenic fungi

\section{INTRODUCTION}

Due to the decorative qualities of its flowers, rhododendron (Rhododendron L.) is a popular shrub in home gardens. The infection of rhododendron inflorescence buds by pathogenic fungi causes their browning, withering and dieback.
The main cause of dieback of inflorescence buds is the fungus Pycnostysanus azaleae. Other pathogens involved in the process of dieback of inflorescence buds are as follows: Alternaria alternata, Botrytis cinerea, Fusarium avenaceum, Epicoccum nigrum, Aureobasidium pullulans, Sclerotinia sclerotiorum, and fungus-like organisms Phytophthora spp. (C z e k a lski and Fruży ńs k a - Jóźwi a k, 1995; Werner et al. 1996, 1998; Frużyńska-Jóźwiak and Werner, 2000; Garibaldi et al. 2002).

According to Kryczyński and Weber (2010), in breeding practice resistance to diseases is the trait taken into consideration while constructing the cultivar ideotype, therefore the identification of the agents causing the infection of rhododendron inflorescence buds may be contributive to creating new improved cultivars revealing genetically determined resistance.

The present study aimed to identify fungi causing dieback of rhododendron (Rhododendron L.) inflorescence buds.

\section{MATERIALS AND METHODS}

The investigations were conducted in 20102011 on the collection of ornamental plants of the Faculty of Horticulture, University of Agriculture in Krakow, using ten Rhododendron L. taxa. These were newly bred hybrids: $R$. brachycarpum $\mathrm{x} R$. brachycarpum, $R$. brachycarpum $\times$ $R$. purdomii, $R$. aureum $\mathrm{x}$ $R$. brachycarpum, $R$. aureum x Koichiro Wada, Koichiro Wada x $R$. aureum, Koichiro Wada x R. brachycarpum, $R$. purdomii x Koichiro Wada, $R$. aureum $\mathrm{x}$ Catharine van Tol, $R$. yakushimanum x Catharine van Tol, and $R$. purdomii species. 
The study material comprised necrotic inflorescence buds, 20 pieces collected from 4-5 shrubs of individual taxa. A total of 400 fragments of buds were analyzed.

Mycological analysis was performed by means of standard methods used in phytopathology. Taxonomic identification of fungi species was conducted using the keys of: Guba (1961), D o m s ch et al. (1980), Ellis and Ellis (1987), R if a i (1987). The basis of classification was the system of K i r k et al. (2008) and the authors' epithets by the fungal names were verified according to In d e x F u n g o r u m (2012).
In terms of the percentage of species in the whole community, the division was made, after Kow a lik (1993), into dominants, influents, and accessory fungi.

\section{RESULTS}

569 fungi colonies were isolated from rhododendron (Rhododendron L.) inflorescence buds with symptoms of browning and withering. The fungi belonged to 31 species within 20 genera (Table 1).

Table 1

Fungi isolated from dead inflorescence buds of rhododendron

\begin{tabular}{|c|c|c|c|c|c|c|}
\hline \multirow{2}{*}{ Fungus } & \multicolumn{2}{|c|}{$\begin{array}{c}\text { Number of } \\
\text { infected buds }\end{array}$} & \multicolumn{2}{|c|}{$\begin{array}{c}\text { Number of } \\
\text { fungal colonies }\end{array}$} & \multirow{2}{*}{\multicolumn{2}{|c|}{$\begin{array}{c}\begin{array}{c}\text { Frequency of Percentage of } \\
\text { occurrence } \\
\text { occurrence }\end{array} \\
2010-2011\end{array}$}} \\
\hline & 2010 & 2011 & 2010 & 2011 & & \\
\hline Alternaria alternata (Fr.) Keissl. & 28 & 17 & 31 & 49 & 80 & 14.06 \\
\hline Alternaria cheiranthi (Lib.) P.C. Bolle & 2 & - & 2 & - & 2 & 0.35 \\
\hline Aspergillus brasiliensis Varga, Frisvard \& Samson & 2 & 1 & 2 & 1 & 3 & 0.53 \\
\hline Aspergillus versicolor (Vuill.) Tirab. & 1 & - & 1 & - & 1 & 0.18 \\
\hline Boeremia exigua (Desm.) Aveskamp, Gruyter \& Verkley var. exigua & 3 & 3 & 4 & 3 & 7 & 1.23 \\
\hline Botrytis cinerea Pers. & 1 & - & 1 & - & 1 & 0.18 \\
\hline Cladosporium herbarum (Pers.) Link & 1 & - & 2 & - & 2 & 0.35 \\
\hline Epicoccum nigrum Link & 12 & 10 & 15 & 13 & 28 & 4.92 \\
\hline Fusarium poae (Peck) Wollenw. & 4 & 2 & 4 & 2 & 6 & 1.05 \\
\hline Mammaria echinobotryoides Ces. & 3 & 2 & 4 & 3 & 7 & 1.23 \\
\hline Mortierella bainieri Costantin & 1 & 1 & 1 & 1 & 2 & 0.35 \\
\hline Mortierella gamsii Milko & 1 & - & 1 & - & 1 & 0.18 \\
\hline Mortierella hyalina (Harz) W. Gams & - & 1 & - & 1 & 1 & 0.18 \\
\hline Mucor racemosus f. sphaerosporus (Hagem) Schipper & 2 & - & 2 & - & 2 & 0.35 \\
\hline Paraphoma chrysanthemicola (Hollós) Gruyter, Aveskamp \& Verkley & 5 & 4 & 6 & 10 & 16 & 2.81 \\
\hline Penicillium expansum Link & 2 & 2 & 3 & 2 & 5 & 0.88 \\
\hline Penicillium waksmanii K.M. Zalessky & 2 & 3 & 2 & 3 & 5 & 0.88 \\
\hline Pestalotiopsis sydowiana (Bres.) B. Sutton & 82 & 49 & 109 & 89 & 198 & 34.80 \\
\hline Phialophora asteris (Dowson) Burge \& I. Isaac & 4 & 5 & 13 & 21 & 34 & 5.98 \\
\hline Phialophora cinerescens (Wollenw.) J.F.H. Beyma & - & 2 & - & 2 & 2 & 0.35 \\
\hline Phialophora cyclaminis J.F.H. Beyma & 4 & 11 & 8 & 17 & 25 & 4.39 \\
\hline Phoma eupyrena Sacc. & 2 & 3 & 3 & 3 & 6 & 1.05 \\
\hline Phoma pinodella (L.K. Jones) Morgan-Jones \& K.B. Burch & - & 3 & - & 3 & 3 & 0.53 \\
\hline Pleurostomophora richardsiae(Nannf.) L. Mostert, W. Gams \& Crous & 1 & 1 & 2 & 1 & 3 & 0.53 \\
\hline Talaromyces wortmannii C.R. Benj. & 3 & 3 & 3 & 6 & 9 & 1.58 \\
\hline Trichoderma koningii Oudem. & 1 & - & 1 & - & 1 & 0.18 \\
\hline Trichoderma pseudokoningii Rifai & 1 & 1 & 1 & 1 & 2 & 0.35 \\
\hline Trichoderma viride Pers. & 8 & 9 & 13 & 17 & 30 & 5.27 \\
\hline Truncatella truncata (Lév.) Steyaert & 19 & 24 & 36 & 42 & 78 & 13.71 \\
\hline Umbelopsis isabellina (Oudem) W. Gams & 3 & 2 & 3 & 4 & 7 & 1.23 \\
\hline Umbelopsis nana (Linnem.) Arx & 2 & - & 2 & - & 2 & 0.35 \\
\hline Total & - & - & 275 & 294 & 569 & 100.0 \\
\hline
\end{tabular}


A comparison of the number of fungal colonies and species on necrotic rhododendron inflorescence buds did not reveal any considerable quantitative differences between growing seasons. In the first year of the study, 275 fungi colonies represented by 28 species were isolated from the inflorescence buds and in the second year 294 colonies within 23 species.

The most frequently isolated fungi were: $P e$ stalotiopsis sydowiana (34.8\%), Alternaria alternata (14.06\%), Truncatella truncata (13.71\%), Phialophora asteris (5.98\%), and Trichoderma viride (constituting $5.27 \%$ of the total isolated colonies). These fungi, classified as dominants, made up in total almost $74 \%$ of the whole community of isolated fungi. Boeremia exigua var. exigua, Epicoccum nigrum, Fusarium poae, Mammaria echinobotryoides, Paraphoma chrysanthemicola, Phialophora cyclaminis, Ph. eupyrena, Talaromyces wortmanii and Umbelopsis isabellina (constituting from 1 to $5 \%$ of the whole community) were classified as influents. They made up over 19\% of the total community. The other 17 species, occurring sporadically, were included in accessory fungi.
The fungi $P$. sydowiana, A. alternata, T. truncata, $T$. viride and $E$. nigrum infested buds of all analyzed taxa. The fungus $F$. poae infected buds of the hybrids $R$. brachycarpum $\mathrm{x}$ R.brachycarpum and $R$. aureum $\mathrm{x}$ Catharina van Tol, while $B$ cinerea infected $R$. aureum $\mathrm{x} R$. brachycarpum.

When comparing the number of colonies and species of isolated fungi, it was observed that rhododendron inflorescence buds were characterized by varying susceptibility to infection. Between 21 and 94 colonies belonging to from 3 to 15 species were isolated from the buds of individual taxa (Table 2). The largest number of fungal colonies was isolated from buds of the hybrids $R$. brachycarpum x $R$. brachycarpum and $R$. purdomii x Koichiro Wada. Infestation of inflorescence buds by fungi in great numbers (expressed by the number of isolated colonies) was correlated with the fungal species diversity, since 14 and 10 species, respectively, were isolated from infected buds. On the other hand, 21 colonies represented only by 3 fungi species were isolated from inflorescence buds of $R$. purdomii.

Table 2

Number of fungal colonies and species on inflorescence buds of particular rhododendron taxa

\begin{tabular}{lcc}
\hline \multicolumn{1}{c}{ Taxon } & Number of fungal colonies & Number of fungal species \\
\hline R. brachycarpum x R. brachycarpum & 90 & 14 \\
R. brachycarpum x R. purdomii & 56 & 5 \\
R. aureum x R. brachycarpum & 47 & 9 \\
R. aureum x Koichiro Wada & 51 & 5 \\
Koichiro Wada x R. aureum & 53 & 4 \\
Koichiro Wada x R. brachycarpum & 59 & 5 \\
R. purdomii x Koichiro Wada & 94 & 10 \\
R. aureum x Catharine van Tol & 48 & 6 \\
Koichiro Wada x Catharine van Tol & 50 & 15 \\
R. purdomii & 21 & 3 \\
\hline
\end{tabular}

The obtained results are evidence of the diversity of fungi colonizing necrotic inflorescence buds of rhododendron.

\section{DISCUSSION}

As reported in the literature data, the agent causing dieback of rhododendron inflorescence buds is the fungus $P$. azaleae syn. Brosia azaleae, identified for the first time in the $19^{\text {th }}$ century in the south-eastern part of the United States, whereas in Poland it was found for the first time in 1994 by Prof. Mieczysław Czekalski. According to numerous descriptions, infected inflorescence buds become brown, take on a silvery tinge, and several millimetre long black synnemata are visible on their surface. The buds shrink, wither and do not open (C z e k a l s ki and Fr uż y ń ska - Jóź wiak, 1995; Glawe and Hummel, 2006). On the bud coats, particularly at the base, there are visible brownish necroses, whereas the number of flowers in the infected bud is reduced (G a rib a ld i et al. 2002). Necrotic buds do not fall off, so there may be between 3 to 5 generations of withered buds on a shrub ( $\mathrm{Fr} \mathrm{u}$ ży ńs ka-Jóźwiak and Werner, 2000; G la we and $\mathrm{Hum} \mathrm{mel}$, 2006).

Czekalski and Frużyńska-Jóźwiak (1995) found that top buds become infected earliest, then side buds, including vegetative ones, leaves and shoots. S t a r k $(1985,1994)$ reports that the pathogen poses a serious threat to rhododendrons in Germany 
where it causes dieback of between $50-75 \%$ of buds. Catharine van Tol (also discussed in this paper), on which over $75 \%$ of buds died, was among the most infected varieties.

The research conducted by Ko w a lik (2009) in 2004-2007 on the collection of the Jagiellonian University Botanical Garden demonstrated the occurrence of $P$. azalea on rhododendron leaves.

The fungus $P$. azalea was not identified in the present study. It did not infest necrotic inflorescence buds. Therefore, the community of pathogenic and saprophytic fungal colonies with the following fungi occurring in large numbers: $P$. sydowiana (syn. Pestalotia sydowiana), A. alternata, T. truncata (syn. Pestalotia truncata), Ph. asteris (syn. Phialophora fastigiata), E. nigrum (syn. Epicoccum purpurascens), $T$. viride and Phialophora cyclaminis, can be regarded as the cause of dieback of inflorescence buds. These fungi constantly live in great numbers on fallen and necrotic leaves of azaleas and rhododendrons (K o w a li k, 2008, 2009; K ow alik et al. 2010, 2011, 2012), so they can be a source of primary infection for inflorescence buds. Infestation of buds by A. alternata should be regarded as the most dangerous due to generated mycotoxins causing symptoms of necrosis ( $\mathrm{P} \nmid \mathrm{a} \dot{\mathrm{z}} \mathrm{e} \mathrm{k}$, 2011). The role of this necrotrophic fungus in causing necrosis and leaf spot diseases was described, among others, by K ow a lik (2009).

The papers by Werner et al. $(1996,1998)$ as well as Fruży ńska-Jóźwiak and Werner (2000) documented the occurrence of pathogens and saprophytes of: Fusarium, Sclerotinia, Botrytis, Ovulinia, Aureobasidium, Epicoccum, and Pestalotiopsis, on rhododendron buds and flowers. The research conducted by Kowalik $(2008,2009)$ and Kowalik et al. $(2011,2012)$ emphasized the role of E. nigrum, $P$. sydowiana and $T$. truncata as necrophytes causing dieback of rhododendron leaves.

W e rn e r et al. (1996) found that the cause of spot disease of flower petals was the fungus $B$. cinerea, abundantly isolated from the infected organs, whereas Fruży ńska-Jóźwiak and Werner (2000) wrote about its devastating effect on buds and inflorescences. Under the conditions of high air humidity, the fungus infested rhododendron leaves (K o w a $1 \mathrm{i} \mathrm{k}$, 2009; K o w a lik et al. 2012), whereas in the present investigations only single cases of occurrence of this pathogen were noted.

The fungi isolated only sporadically from dead inflorescence buds of the analyzed rhododendron taxa were as follows: Mortierella, Umbelopsis, Trichoderma, Phoma, and Paraphoma. According to K owalik et al. (2010, 2011, 2012), these fungi exist on leaves and also greatly increase the necrotization process.
Fungi living on inflorescence buds may cause infections at the flowering stage, which leads to withering and dieback of inflorescences and as a result reduces the decorative qualities of these plants.

The assessment of fungal infection of inflorescence buds in newly bred rhododendron taxa allows us to conclude that they reveal genetically determined resistance to pathogens. The results of mycological analysis can be useful for breeders, because they indicate parental forms with high susceptibility to infection by fungi causing dieback of inflorescence buds.

\section{CONCLUSIONS}

1. Inflorescence buds of newly bred rhododendron taxa (Rhododendron L.) were characterized by varying susceptibility to infection by fungi causing their dieback. Browning and withering of buds were caused by pathogenic and saprophytic fungi, among which Pestalotiopsis sydowiana, Alternaria alternata, Truncatella truncata, Phialophora asteris and Trichoderma viride played the dominant role.

2. The taxa $R$. aureum and $R$. purdomii can be valuable parental forms for further breeding work. Inflorescence buds of the hybrids originating from these parental forms were infested by relatively few fungi species.

3. The hybrids $R$. brachycarpum $\mathrm{x} R$. brachycarpum and $R$. purdomii x Koichiro should be excluded from further breeding work due to the documented existence of several times more numerous colonies and species of fungi causing dieback on their inflorescence buds.

\section{Acknowledgements}

Research supported by the Ministry of Science and Higher Education of Poland as part of the statutory activities of the Department of Plant Protection, University of Agriculture in Kraków.

\section{Authors' contributions}

The following declarations about authors' contributions to the research have been made: concept of the study: MK, MŻ; determination of the specimens: $\mathrm{MŻ}, \mathrm{BKB}$; writing the manuscript: MK, MŻ.

\section{REFERENCES}

Czekalski M., Frużyńska-Jóźwiak D. 1995. Obumieranie pąków kwiatostanowych różaneczników wywoływane przez grzyb Pycnostysanus azaleae (Pech) Mason. / Flower bud blast caused by the fungus Pycnostysanus azaleae (Pech) Mason. Erica Polonica, 6: 7-14. (in Polish) 
Domsch K.H., Gams W., Anderson T.H. 1980. Compendium of Soil Fungi. Acad. Press. London, New York, Toronto, Sydney, San Francisco, 859 pp.

E11 is M.B., E11 is J.P. 1987. Microfungi on Land Plants. An Identification Handbook. Croom Helm. London, Sydney, 818

Fruży ńska-Jóźwiak D., Werner M. 2000. Grzyby wyniszczające pąki i kwiatostany różanecznika. / Fungi destroying buds and inflorescences of rhododendron. Ochrona Roślin, 3: 37-38. (in Polish)

Garibaldi A., Gilardi G., Bertetti D., Gullino M.L. 2002. First report of Pycnostysanus azaleae on Rhododendron in Italy. The American Phytopathological Soc. 86 (5): 560.

Glawe D.A., Hummel R.L. 2006. New North American host records for Seifertia azaleae, cause of Rhododendron bud blight disease. Pacific Northwest Fungi, 1 (5) 1-6.

Guba E.F. 1961. Monograph of Monochaetia and Pestalotia. Harvard Univ. Press, Cambridge, 255 pp.

Index Fungorum. On line www.indexfungorum.org.names/Names.asp, accessed on 10.10.2012.

Kirk P.M., Cannon P.F., Minter D.W., Stalpers J.A. 2008. Ainswort \& Bisby's Dictionary of the Fungi. CAB International, Wallingford, UK.

Kowalik M. 1993. Grzyby gleby inicjalnej industroziemnej rekultywowanego w kierunku rolnym i leśnym zwałowiska Kopalni siarki „Machów”. Zesz. Nauk. Akademii Rolniczej im. H. Kołłąaja w Krakowie. Rozprawa hab. 180, 78 pp. (in Polish)

Kowalik M. 2008. Fungi and fungi-like Oomycetes isolated from affected leaves of rhododendron. Acta Mycol. 43 (1): 21-27.

Kowalik M. 2009. Bioróżnorodność grzybów występujących w fyllosferze różanecznika zimozielonego Rhododendron L. / Biodiversity of fungi occurring in phyllosphere of evergreen rhododendron Rhododendrons $\mathrm{L}$. Zesz. Probl. Post. Nauk Roln. 539: 341-348. (in Polish)

Kowalik M., Kierpiec B., Bonio J., Żołna M. 2011. Fungi inhabiting spots and necroses on the leaves of azaleas (Rhododendron L.) in the Botanical Garden of the Jagiellonian University. Phytophatologia, 62: $41-48$.

Kowalik M., Muras P., Żołna M., Kierpiec B. 2010. Grzyby wyosobnione z nekrotycznych plam na liściach różaneczników zawsze zielonych Rhododendron L. / Fungi isolated from necrotic spots on the leaves of evergreen rhododendrons Rhododendrons L. Zesz. Probl. Post. Nauk Roln. 554: 49-55. (in Polish)

Kowalik M., Żołna M., Kierpiec B. 2012. Fungi living at the fallen leaves of rhododendron and azalea (Rhododendron L.). Acta Sci. Pol. Hortorum Cultus, 11 (2): 161-166.

Kryczyński S., Weber Z. (ed). 2010. Fitopatologia, t.1., Podstawy Fitopatologii, 639 pp. (in Polish)

Płażek A. 2011. Patofizjologia Roślin. Wydawnictwo Uniwersytetu Rolniczego w Krakowie, 140 pp. (in Polish)
R ifai M.A. 1987. A revision of the genus Trichoderma. Mycol. Papers, 116: 1-56.

St ark Ch. 1985. Das Rhododendron-Knospensterben. Rhododendron immergrüne Laubgehölze Jahrb.: 76-79. (in German)

Stark Ch. 1994. Das Rhododendron-Knospensterben. [In:] Offizieller Katalog Rhodo'94. Plois, Westerstede: 4549. (in German)

Werner M., Czekalski M., Frużyńska-Jóźwiak D. 1996. Plamistość płatków kwiatowych różaneczników w Polsce. / Petal blight on rhododendrons in Poland. Erica Polonica, 7: 52-55. (in Polish)

Werner M., Frużyńska-Jóźwiak D., Czekalski M. 1998. Analiza mikologiczna nie rozkwitających kwiatostanów różaneczników. / Mycological analysis of rhododendron inflorescences that fail to open. Erica Polonica, 9: 60-63. (in Polish)

\section{Różnorodność grzybów zasiedlających obumarłe pąki kwiatostanowe różanecznika zawsze zielonego (Rhododendron $\mathbf{L}$.)}

\section{Streszczenie}

Porażenie pąków kwiatostanowych różanecznika zawsze zielonego (Rhododendron L.) przez grzyby chorobotwórcze powoduje ich brunatnienie, zasychanie i obumieranie. Określenie sprawców porażenia pąków kwiatostanowych różanecznika może stanowić przyczynek do tworzenia nowych, ulepszonych odmian wykazujących genetycznie warunkowaną odporność na patogeny.

Badania prowadzono w latach 2010-2011, w kolekcji roślin ozdobnych Wydziału Ogrodniczego Uniwersytetu Rolniczego w Krakowie. Materiał badawczy stanowiły porażone pąki kwiatostanowe pobrane z dziewięciu nowo wyhodowanych taksonów i jednego gatunku botanicznego różanecznika zawsze zielonego. Z porażonych wierzchołkowych pąków kwiatostanowych różanecznika wyizolowano 569 kolonii grzybów, należących do 31 gatunków. Wśród grzybów dominowały: Pestalotiopsis sydowiana, Truncatella truncata, Alternaria alternata, Phialophora asteris i Trichoderma viride, stanowiąc prawie $74 \%$ całości zbiorowiska wyodrębnionych grzybów. W mniejszej liczbie wyodrębniono: Boeremia exigua var. exigua, Epicoccum nigrum, Fusarium poae, Mammaria echinobotryoides, Paraphoma chrysanthemicola, Phialophora cyclaminis, Phoma eupyrena, Talaromyces wortmannii, Umbelopsis isabellina i inne.

Wyniki analizy mykologicznej potwierdziły różnorodność gatunkową grzybów zasiedlających porażone, obumarłe pąki kwiatostanowe różanecznika zawsze zielonego. 
